\title{
R8. DETECÇÃO DE ZIKA, DENGUE E CHIKUNGUNYA EM ENSAIO MOLECULAR MULTIPLEX.
}

Patrícia Alvarez ${ }^{1}$; Elisabete Andrade ${ }^{1}$; Daniele Rocha ${ }^{1}$; Marcela Fontana ${ }^{1}$; Marisa Ribeiro ${ }^{1}$; Elaine Costa $^{1}$; Daniela T. Godoy ${ }^{1}$; Antonio Ferreira ${ }^{1}$.

${ }^{1}$ Bio-Manguinhos.

INTRODUÇÃO Os vírus Zika, Dengue e Chikungunya causam uma variedade de síndromes com sintomas muito semelhantes. Atualmente, médicos têm lidado cada vez mais com pacientes com essas doenças. Neste contexto, o diagnóstico laboratorial diferencial se torna uma ferramenta de grande importância para determinar a etiologia da doença e construir a nossa compreensão da epidemiologia e importância médica dos arbovírus.

OBJETIVO Desenvolver um ensaio molecular multiplex, capaz de detectar e discriminar os vírus Zika, Dengue e Chikungunya em amostras clínicas de pacientes suspeitos.

METODOLOGIA Um ensaio molecular multiplex discriminatório, one-step, PCR em tempo real para Zika, Dengue e Chikungunya, com um controle interno (CI), foi padronizado com vírus de cultura. Amostras de pacientes com suspeita clínica foram utilizadas para acessar a performance do ensaio. De outubro de 2015 a fevereiro de 2016, plasmas foram coletados dos pacientes suspeitos. O RNA foi extraído com o equipamento MDX (Qiagen), as reações de PCR em tempo real foram pipetadas automaticamente no Janus (PerkinElmer) e amplificação feita no sistema QuantStudio (Life Technologies). Este ensaio triplex foi padronizado com primers e sondas gêneroespecíficos otimizados para detectar e discriminar os vírus Zika, Dengue, Chikungunya e o CI.

RESULTADOS O ensaio foi ajustado para performance satisfatória, reprodutibilidade, especificidade e alta sensibilidade. $\mathrm{O}$ CI monitorou e validou todos os passos e reações. O threshold foi fixado em 0,3. Oito replicatas, de diluições seriadas de base 10 $\left(10-10^{6}\right)$, de vírus Zika, Dengue e Chikungunya de cultura, foram analisadas e 100\% delas foi detectada. Um total de 309 amostras de pacientes com suspeita clínica de Zika, Dengue e Chikungunya foram analisadas. O ensaio molecular multiplex detectou 
27 pacientes positivos para Zika, 9 para Dengue e 63 para Chikungunya, confirmando uma fase aguda da infecção, comprovada pela presença do RNA de vírus circulante. O diagnóstico laboratorial Zika, Dengue e Chikungunya é desafiador, o RNA viral é detectado no soro de pacientes apenas durante os primeiros dias da doença. Em um desses pacientes confirmado para Zika vírus pelo ensaio molecular multiplex, no início dos sintomas, foi possível detectar o vírus na urina nove dias após o início dos sintomas, momento em que o vírus não estava mais presente no soro.

CONCLUSÃO A rápida implementação do ensaio molecular multiplex Zika/ Dengue/Chikungunya (ZDC) no Brasil irá ajudar no manejo dos pacientes e a identificar regiões endêmicas. Todas as características técnicas de sensibilidade, especificidade e reprodutibilidade foram definidas em tempo recorde. A prova de conceito deste novo ensaio diagnóstico molecular ZDC foi obtida através do processamento pareado de amostras clínicas. A incorporação desta proposta de kit ZDC Brasileiro é uma realidade e está em fase de produção e validação de lotes piloto, visando à submissão de processo junto a ANVISA.

PALAVRAS-CHAVE diagnóstico molecular / Zika, Dengue e Chikungunya. 